\title{
PSORALEA PALLIDA, A NEW SPECIES OF FABACEAE FROM ARID AUSTRALIA
}

\author{
NANCY T. BURBIDGE $†$
}

(Accepted for publication 2.11.1979)

\begin{abstract}
Burbidge, Nancy T. (Herbarium Australiense, CSIRO, P.O. Box 1600, Canberra City, Australia 2601) 1980. Psoralea pallida, a new species of Fabaceae from arid Australia. Telopea 2(1): 127-128.-P. pallida. a common inhabitant of the sand dunes of Central Australia and particularly of the Simpson Desert, extending into adjacent areas of Queensland, New South Wales and South Australia and into northwestern Victoria, is described.
\end{abstract}

Psoralea pallida N.T. Burbidge, sp. nov.

Species affinis $P$. erianthae Benth. sed plus tomentosa et flosculis majoribus.

Herba robusta, villoso-tomentosa, ramis striatis stipulis lanceolatis, acuminatis villosisque. Folia pinnati-trifoliolata, petiolata. Foliola rhomboidea vel ovata, obtusa, supra tomentosa, sparsim glandulosa, subter dense tomentosa, marginibus denticulatis interdum repando-denticulatis dentibus apiculatis. Racemi axillares, pedunculati, pedunculis quam folia subtenta brevioribus, raro longioribus. Calyx bilabiatus, dense villosus, $8-10 \mathrm{~mm}$ longus, lobo infimo cymbiforme tubum vix excendente, lobis lateralibus manifeste quam ceteros brevioribus. Corolla purpurascens, vexillo calycis lobo infimo vix excedente. Legumen villosum $3.5-4 \mathrm{~mm}$ longum.

Holotype: App. 22 miles [c. $35 \mathrm{~km}$ ] south of Alice Springs, on railway line road. N. T. Burbidge \& M. Gray, 4379, 29.9.1955 (CANB 241936). IsOTYPES: CANB, NSW; to be sent: K, PERTH.

Robust erect or ascendent herb, grey-pubescent or villous on all parts except the corolla. Stems striate, thickly tomentose-villous and without visible glands. Stipules lanceolate, acuminate, villous. Leaves pinnately trifoliolate, petioles $2-4 \mathrm{~cm}$ long; leaflets rhomboid-ovate, obtuse, incurved-undulate and apiculate-denticulate on the margins, tomentum thinner above but the glands few or obscured, terminal leaflet 3-5 cm long. Racemes axillary, loosely compact, pedunculate, not interrupted at the base. Peduncles usually shorter than the subtending leaves, vestiture as on stems. Flowers in threes, subsessile in the axils of ovate villous bracts $2 \mathrm{~mm}$ long. Calyx bilabiate, villous, $8-10 \mathrm{~mm}$ long; lowest lobe slightly longer than tube, laterals less than half as long and upper lobes about two-thirds as long as lowest. Corolla purplish, as long as lowest calyx lobe or slightly longer. Pod 3.5-4 mm long, villous especially towards the apex.

Specimens Examined: Oueensland: Gregory North: "Currawilla" 100 miles [161 km] W. of Windorah, Everist 3985, 6.1949 (BRI). Gregory : South: "South Galway", 45 miles [73 km] SW. of Windorah, Everist 4038, 6.1949, flowers pink and lowest lobe of calyx unusually long and upcurved (BRI); sandhills W. of Birdsville, Everist \& Smith 88, 1.1937 (BRI); 90 miles $[145 \mathrm{~km}]$ N. of Tibooburra, Riek \& Common 0212, 11.1940 (CANB).

New South Wales: Far Western Plains: 10 miles [16 km] S. of "Cobham", Riek \& Common 0307, 11.1949 (CANB); Cobham sand hills, Morris 10.1921 (BRI); Wilcannia, Corbett 10.1901 (K); Darling R., Dallachy \& Goodwin (K); sandhills near Menindee, Beckler, Victorian Expedition (K).

$\uparrow$ died 4 Mar 1977. This paper publishes manuscript left by Dr Burbidge, with slight emendation by Alma T. Lee (National Herbarium of New South Wales, Royal Botanic Gardens, Sydney 2000). 
VICTORIA: Mildura, Williamson 10.1928 (K).

South Australia: Lake Eyre Basin: Bradys Waterhole, “Cordillo [Downs]", Basedow 60, $10.1919(\mathrm{~K})$.

Northern Territory: Central Australia: 30 iniles [48 km] SW. of Alice Springs, Gardner $11670,3.1953$ (PERTH).

This species resembles $P$. eriantha and was confused with it by Domin [Biblioth. Bot. $\left.22\left(89^{2}\right): 738(1925)\right]$. It differs in the more robust habit, larger flowers with a relatively longer lowest lobe to the calyx and in the denser pale grey vestiture. The pod is enclosed in the slightly oblique calyx in a similar fashion to that in $P$. eriantha. In some specimens where the calyx lobes are relatively long the lowest lobe is upcurved.

Manuscript received 12.10 .1979 